\title{
Zucchini yellow mosaic virus: Contact Transmission, Stability on Surfaces, and Inactivation with Disinfectants
}

B. A. Coutts, M. A. Kehoe, and R. A. C. Jones, Crop Protection Branch, Department of Agriculture and Food Western Australia, Bentley Delivery Centre, Perth, WA 6983, and School of Plant Biology and Institute of Agriculture, Faculty of Science, University of Western Australia, Crawley, WA 6009, Australia

\begin{abstract}
Coutts, B. A., Kehoe, M. A., and Jones, R. A. C. 2013. Zucchini yellow mosaic virus: Contact transmission, stability on surfaces, and inactivation with disinfectants. Plant Dis. 97:765-771.

In glasshouse experiments, Zucchini yellow mosaic virus (ZYMV) was transmitted from infected to healthy zucchini (Cucurbita pepo) plants by direct contact when leaves were rubbed against each other, crushed, or trampled, and, to a lesser extent, on ZYMV-contaminated blades. When sap from zucchini plants infected with three ZYMV isolates was kept at room temperature for up to $6 \mathrm{~h}$, it infected healthy plants readily. Also, when sap from ZYMV-infected leaves was applied to seven surfaces (cotton, plastic, leather, metal, rubber vehicle tire, rubbersoled footwear, and human skin) and left for up to $48 \mathrm{~h}$ before the ZYMV-contaminated surface was rubbed onto healthy zucchini plants, ZYMV remained infective for $48 \mathrm{~h}$ on tire, $24 \mathrm{~h}$ on plastic and leather, and up to $6 \mathrm{~h}$ on cotton, metal, and footwear. On human skin, ZYMV remained infective for $5 \mathrm{~min}$ only. The effectiveness of 13 disinfectants

at inactivating ZYMV was evaluated by adding them to sap from ZYMV-infected leaves which was then rubbed on to healthy zucchini plants. None of the plants became infected when nonfat dried milk $(20 \%, \mathrm{wt} / \mathrm{vol}$ ) or bleach (sodium hypochlorite at $42 \mathrm{~g} / \mathrm{liter}$, diluted 1:4) were used. When ZYMV-infected pumpkin leaves were trampled by footwear and then used to trample healthy plants, all plants became infected; however, when contaminated footwear was dipped in a footbath containing bleach (sodium hypochlorite at $42 \mathrm{~g} /$ liter, diluted 1:4) before trampling, none became infected. This study demonstrates that ZYMV can be transmitted by contact and highlights the need for onfarm hygiene practices (decontaminating tools, machinery, clothing, and so on) to be included in integrated disease management strategies for ZYMV in cucurbit crops.
\end{abstract}

Zucchini yellow mosaic virus (ZYMV; family Potyviridae, genus Potyvirus) is one of the most economically important viruses of cucurbit crops worldwide. When cucurbit crops become infected early by ZYMV, losses in yield and marketable fruit can be up to $100 \%(3,10,13,15)$. ZYMV was first found in Italy in 1973 and described in 1981 (26). Subsequently, it has been identified in more than 50 countries across five continents (13), and epidemics of ZYMV within cucurbit crops now occur worldwide $(14,17$, 28,46). ZYMV is nonpersistently transmitted by a number of cucurbit colonizing and noncolonizing aphid species (23), is seedborne at low levels in some cucurbit species $(11,15,38,40,44)$, and has a limited number of naturally occurring hosts which can act as infection reservoirs outside the cucurbit growing period $(9,11,13,34,42)$. Many studies have investigated the molecular properties of ZYMV $(1,11,13,14,50)$. Control measures have also been studied and integrated disease management approaches devised $(10,13,32)$ but controlling spread of the virus successfully in cucurbit crops has still proven difficult. This difficulty and the spread of ZYMV within cucurbit crops when aphids are apparently absent suggests that there may be other methods by which ZYMV is transmitted that are not being addressed by current control measures.

Plant viruses can be transmitted by vegetative propagation, vectors, seed, pollen, or contact. Readily contact-transmitted viruses typically have stable virus particles that reach very high concentrations within the epidermal cells of infected plants $(2,30)$. Also, for

Corresponding author: B. A. Coutts,

E-mail: brenda.coutts@agric.wa.gov.au

* The $\boldsymbol{e}$-Xtra logo stands for "electronic extra" and indicates that Figure 1 appears in color online.

Accepted for publication 11 January 2013.

http://dx.doi.org/10.1094/PDIS-08-12-0769-RE

(C) 2013 The American Phytopathological Society successful contact transmission, the host plant needs to be easily wounded during abrasion such that the leaf epidermis is slightly damaged, enabling virus particles to penetrate its cuticle and cells, where the virus can replicate (30). Under natural conditions in the field, sublethal wounding of plant cells occurs readily during normal leaf abrasion, cultivation practices, and other types of foliar contact, including with animals and man (16). Most examples of such viruses are in the genera Carlavirus (e.g., Potato virus $S$ [PVS]), Sobemovirus (e.g., Rice yellow mottle virus [RYMV] and Subterranean clover mottle virus [SCMoV]), Tobamovirus (e.g., Hibiscus latent Fort Pierce virus [HLFPV], Odontoglossum ringspot virus [ORSV], and Tobacco mosaic virus [TMV]), and Potexvirus (e.g., Cymbidium mosaic virus [CyMV], Pepino mosaic virus [PepMV], Potato virus $X[\mathrm{PVX}]$, and White clover mosaic virus [WCMV]). These viruses spread directly from infected to healthy plants when leaves rub together under the influence of wind. They also spread indirectly (i) when infective sap-contaminated clothes, hands, cutting or pruning tools, equipment, or machinery come into contact with healthy plant material or (ii) animals graze and trample infected plants before moving to healthy plants $(6,19,21,22,31,36,37,41,45)$. Viruses in the family Potyviridae differ in that their particles are less stable and occur at lower concentration in plant cells $(27,30)$. However, there are several reports that they spread to a limited extent by contact: Wheat streak mosaic virus spread in wheat when leaves of infected plants brushed against healthy plants $(4,39)$, Potato virus $Y$ spread from infected to healthy glasshouse grown tomato plants on contaminated tools during pruning (48), and Bean yellow mosaic virus was transmitted between gladiolus plants on cutting tools (5). There is some anecdotal evidence that ZYMV spreads within cucurbit crops by contact. Fletcher et al. (15) suggested that spread was by machinery because plants with disease symptoms were prevalent along machinery tracks. Similarly, Riedle-Bauer (35) suggested that wounds created during mechanical weed control operations allow plant-to-plant spread of ZYMV and that its particles may also be carried by vertebrates, such as rabbits. However, there is no experimental evidence to support these suggestions. 
PVX survived and remained infective for up to $3 \mathrm{~h}$ on metal and rubber surfaces and up to $6 \mathrm{~h}$ on cotton fabric, while PVS remained infective on these surfaces for up to $25 \mathrm{~h}(16,45,49)$. TMV also survived for several weeks on various glasshouse surfaces and clothing (6). For viruses spread on contaminated cutting tools, clothing or machinery, disinfectants can be used to inactivate and control virus spread between plants. Their effectiveness and usefulness depends on the type of disinfectant, its concentration, and its incubation time, as well as considerations such as availability, cost, and potential toxicity to humans and plants. Trisodium phosphate (10\% for $30 \mathrm{~s}$ ) inactivated TMV and PVX, and was considered safe for equipment and hands (7). For CyMV and ORSV, NaOH (1\%) was effective at inactivating both viruses without causing phytotoxic damage (19). Seven disinfectants were effective at eliminating PepMV from five common glasshouse surfaces (33). Treating contaminated cutting tools with $10 \%$ sodium hypochlorite or $20 \%$ nonfat dry milk was effective at preventing HLFPV infection during plant propagation and pruning (22). Use of $20 \%$ nonfat dry milk plus $0.1 \%$ Tween 20 or household bleach ( $0.6 \%$ sodium hypochlorite, 1:10 dilution) on contaminated cutting tools completely eliminated TMV transmission to petunias (25).

Traditional measures of virus stability and concentration in vitro, including thermal inactivation point, dilution end point, and longevity in vitro, provide an indication of virus stability and, therefore, ability to be contact transmitted (2). Tobamovirus spp. have thermal inactivation points of 80 to $95^{\circ} \mathrm{C}$, their sap remains infective at room temperature for decades, and they have dilution end points of $10^{-5}$ to $10^{-6}$ (18). Similarly, Potexvirus spp. have thermal inactivation points of 60 to $80^{\circ} \mathrm{C}$, longevities in vitro of weeks to months, and dilution end points of $10^{-5}$ to $10^{-6}(24)$. In contrast, ZYMV has a thermal inactivation point of $55^{\circ} \mathrm{C}$, sap remains infective up to 3 days, and the dilution end point is $10^{-4}(27)$. This might be interpreted as indicating contact transmission of ZYMV is less likely.

This article describes a series of glasshouse experiments undertaken with ZYMV to determine (i) whether it can be transmitted to healthy plants by leaf rubbing, via crushing and trampling, or on contaminated blades; (ii) its stability in sap over time and on seven surfaces; and (iii) the effectiveness of 13 disinfectants in inactivating it in sap.

\section{Materials and Methods}

For the purposes of this investigation, mechanical transmission refers only to experimental inoculation with sap from ZYMV-infected leaves containing an abrasive (e.g., diatomaceous earth), whereas contact transmission refers to when infected plant material comes into contact with healthy plants in the absence of an abrasive without causing visible damage. Wound-mediated transmission refers to the severe form of contact transmission, where wounding causes visible damage such as cuts or bruises.

Virus isolates, plants, inoculations, and antiserum. All plants were grown in insect-proof, air-conditioned glasshouses maintained at 18 to $22^{\circ} \mathrm{C}$. Plants of zucchini (Cucurbita pepo) 'Blackjack' and 'Jarrahdale'-type pumpkin (C. maxima) 'WA Grey' were grown in pots in a steam-sterilized soil, sand, and peat mix (1:1:1). Zucchini plants were used in all experiments, except trampling experiments that used pumpkin plants. ZYMV isolates $\mathrm{KnX}-1$, Cvn-1, Nt-1, and Vic-1 were from previous studies $(10,11)$. They were maintained in zucchini plants by mechanical inoculation and were the sources of ZYMV inoculum for glasshouse experiments. For mechanical inoculation to maintain cultures, ZYMV-infected leaves were ground in $0.1 \mathrm{M}$ phosphate buffer, $\mathrm{pH} 7.2$, and the sap was mixed with celite before being rubbed onto the leaves of plants. Leaf samples from plants infected with isolate Knx-1 culture were used as the positive control in enzyme-linked immunosorbent assay (ELISA). The polyclonal antiserum to ZYMV was from Prime Diagnostics.

ELISA. To test for ZYMV infection, leaf samples were extracted singly in phosphate-buffered saline $(10 \mathrm{mM}$ potassium

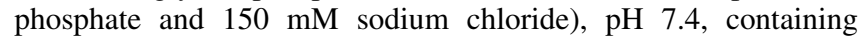
Tween 20 at $5 \mathrm{ml} /$ liter and of polyvinyl pyrrolidone at $20 \mathrm{~g} / \mathrm{liter}$, using a mixer mill (Retsch). Sample extracts were tested for ZYMV by double-antibody sandwich ELISA (8). Each sample was tested in duplicate wells in microtiter plates and appropriate infected and healthy leaf samples were included in duplicate wells as controls. The substrate used was $p$-nitrophenyl phosphate at 1.0 $\mathrm{mg} / \mathrm{ml}$ in diethanolamine, $\mathrm{pH} 9.8$, at $100 \mathrm{ml} /$ liter. Values for absorbance at $405 \mathrm{~nm}$ were measured in a microplate reader (BioRad Laboratories). Positive absorbance values were always at least 10 times those of healthy sap.

Contact-mediated transmission. To investigate whether ZYMV could spread from infected to healthy plants by leaf-to-leaf contact, a zucchini leaf infected with ZYMV isolate Knx-1, Cvn-1, Vic-1 (two experiments each), or Nt-1 (one experiment) was gently rubbed onto the leaf surface of a healthy zucchini plant, such that no visual damage occurred. For each isolate, the upper leaf surface of 6 or 10 plants with two fully expanded leaves each were rubbed with an infected leaf. The same numbers of plants were rubbed with healthy zucchini leaves as controls. All plants were examined for symptom development, and a single newly emerged leaf was sampled from each plant at 20 to 21 days after rubbing and tested individually by ELISA.

Wound-mediated transmission. To simulate virus transmission on contaminated tools, such as knives used to harvest cucurbit fruit, a scalpel with a blade (size 22) was used to cut through a leaf petiole or small fruit of a zucchini plant infected with ZYMV isolate Knx-1 (three experiments). This blade was then used to cut through leaf petioles of a healthy zucchini plant, such that the leaf was completely cut off. Each plant had six leaves and scalpel blades were changed between each plant. The numbers of petioles or fruit cut were one, three, or five per infected plant followed by the same number of petiole cuts on the healthy plant. In all, 5 or 10 plants were used for each type of cutting combination. There were also two healthy control plants for each cutting treatment in which leaf petioles or fruit were cut from healthy plants before cutting the control plants. In addition, five plants were included as a positive control in which leaf-to-leaf rubbing occurred, as was used in the contact-mediated transmission experiments. A single newly emerged tip leaf was sampled from each plant and tested individually by ELISA up to 39 days after cutting.

Four experiments were done to simulate virus transmission by leaf crushing, such as when leaves are damaged by machinery or vehicle tires. A rubber mallet with Parafilm secured with an elastic band to cover its head ( $5 \mathrm{~cm}$ in diameter) was used to tap zucchini leaves infected with isolates $\mathrm{Knx}-1$ or Cvn-1 (two experiments each). This rubber mallet was then used to tap a leaf of a healthy zucchini plant (Fig. 1A and B). The number of taps was one, three, or five on an infected plant leaf followed by the same number of taps on the upper leaf surface of a healthy plant. Leaves were placed on newspaper for tapping. The Parafilm was replaced between each plant. There was a negative control in which leaves of healthy plants were tapped in the same way before tapping the leaf of a healthy plant. Also, a positive control was included in which leaf-to-leaf rubbing occurred. Five plants were used for each tapping treatment. A single newly emerged leaf was sampled from each plant up to 37 days after mallet inoculation and tested individually by ELISA. All plants were examined for tapping damage and symptom development.

An experiment was done to simulate virus transmission by trampling caused by movement of humans through a cucurbit crop. Pumpkin plants were grown in large pots and placed so that their leaves grew over the glasshouse floor. Four groups, each with nine pots (two plants per pot) were arranged so that at least $5 \mathrm{~m}$ separated each group. The experimental treatments were applied 55 days after sowing and were (i) pumpkin leaves infected with Knx-1 trampled 10 times with rubber-soled shoes and then healthy plants trampled; (ii) as for (i) but healthy leaves trampled initially; (iii) infected leaves run over five times by a tire of a filled wheelbarrow and then healthy plants run over; and (iv) plants not trampled or run over (control). A single newly emerged leaf was sampled from each plant 21 days after trampling and tested individually by ELISA. 
Stability. Five experiments were done to establish the stability of ZYMV infectivity. Sap was extracted from zucchini leaves infected with ZYMV isolate Knx-1 (two experiments), Cvn-1, Nt-1, or Vic-1 (one experiment each) using a leaf press. Sap extracts were incubated and allowed to dry at room temperature for different time periods ( $5 \mathrm{~min}$ to $48 \mathrm{~h}$ ) before distilled water was added to resuspend them. For each time period, $2 \mathrm{ml}$ of sap extracts containing ZYMV isolates $\mathrm{Knx}-1$ or Cvn- 1 were placed into individual holes in a 12-hole metal muffin baking tray, or $1.5 \mathrm{ml}$ of sap extracts containing ZYMV-isolates $\mathrm{Knx}-1$, Nt-1, or Vic-1 were placed into individual porcelain bowls. For isolate $\mathrm{Knx}-1$, the infective sap was left for 5 or $30 \mathrm{~min}$ or $1,3,6,24$, or $48 \mathrm{~h}$ before $1.5 \mathrm{ml}$ of distilled water was added to resuspend it. For isolates Knx-1 and Cvn-1, the time periods were 5 and $30 \mathrm{~min}$ and 1, 2, 3, and $6 \mathrm{~h}$, after which $2 \mathrm{ml}$ of distilled water was added to resuspend the sap. For isolates Nt-1 and Vic-1, the time periods were as for Cvn-1 but with an additional 24-h period. For each experiment, after each time period, once the sap was resuspended, it was immediately inoculated without buffer or abrasive onto leaves of five zucchini plants (two leaves per plant). Five plants were left uninoculated as controls. A single newly emerged leaf was sampled from each plant up to 27 days after inoculation and tested individually by ELISA.

Two experiments were done to establish the stability of ZYMV on different surfaces. Sap was extracted from zucchini leaves infected with ZYMV isolate Knx-1 using a leaf press and placed on each test surface. The test surfaces were cotton fabric (worn and washed), rubber shoe sole (worn), tire (inner rubber tube), leather (worn boot), metal (steel), plastic (black horticultural plastic mulch), and skin (human). For each surface, $0.5 \mathrm{ml}$ of infective sap was applied to a 2-by-2-cm area. In one experiment, the applied sap was left at room temperature for 5 and 30 min and 1, 6, and 24 $\mathrm{h}$ after application, except with skin, which was left for $5 \mathrm{~min}, 30$ min, and $1 \mathrm{~h}$. In a second repeat experiment, the time periods were $5 \mathrm{~min}$ and 1, 6, 24, and $48 \mathrm{~h}$ and, for skin, were $5 \mathrm{~min}$ and 1 and 6 $\mathrm{h}$. There were five replications of each surface for each time period. For inoculation, the surface contaminated with infective sap was rubbed directly onto the upper surface of leaves of zucchini plants (two leaves per plant). For controls, five plants were left uninoculated for each time period and five plants were inoculated (without buffer or abrasive) with the fresh sap extract. A single newly emerged leaf was sampled from each plant up to 30 days after inoculation and tested individually by ELISA.

Disinfectants. To investigate inactivation of ZYMV by different disinfectants, two methods of inoculation were used.

In the two preliminary experiments, a rubber mallet with Parafilm covering its head was used to tap zucchini leaves infected with ZYMV isolate Knx-1 five times. A disinfectant was then applied to the Parafilm and a leaf of a healthy plant was then tapped five times. The Parafilm was changed between each plant. With each disinfectant or control experimental treatment, five plants were used (three leaves per plant). All disinfectants were diluted in distilled water and used at the manufacturer's recommended rate. Each disinfectant was applied as an aerosol spray to the Parafilm on the mallet (three sprays only), except for the Isowipe treatment, where the wipe was used directly on the Parafilm. For controls, no disinfectant was applied after tapping an infected or healthy leaf, or plants were left undamaged. These preliminary experiments included the following disinfectant treatments: denatured ethanol (70\%), Farmcleanse (alkylbenzene sulfonic acid 1 to 10\%, diluted 1:10), Virkon (potassium peroxymonosulphate $50 \%$ [wt/wt], dilution $0.5 \%$ ), household bleach (sodium hypochlorite at $42 \mathrm{~g} / \mathrm{liter}$, $4 \%$ available chlorine, diluted 1:20 or 1:4), household disinfectant (benzalkonium chloride $1.5 \%$ [wt/wt], diluted 1:20), antibacterial dishwashing concentrate with tinosan HP100 (2-hydroxy-4,4-dichloro-diphenyl ether, diluted $0.4 \%$ ), Menno-Florades ( $9 \%$ benzoic acid, diluted 3\%), Cerama Klen (alkaline salts with available chlorine at $34 \mathrm{~g} / \mathrm{kg}$, diluted $2.5 \%)$, Isowipe bacterial wipes $(70 \%$ [vol/vol] isopropyl alcohol impregnated wipe), and distilled water. A single newly emerged leaf was sampled from each plant up to 42 days after tapping and tested individually by ELISA. A second experiment repeated the initial experiment, except that household disinfectant, dishwashing concentrate, distilled water, and undamaged control treatments were omitted. A single newly emerged leaf was sampled from each plant up to 37 days after inoculation and tested individually by ELISA.

In the three main experiments, sap was extracted from zucchini leaves infected with ZYMV isolate Knx-1 using a leaf press and 1 $\mathrm{ml}$ of extract was diluted with $1 \mathrm{ml}$ of each of the following: nonfat dried milk (20\% [wt/vol]), nonfat dried milk (20\% [wt/vol]) + Tween $20(0.1 \%)$, Tween $20(0.1 \%)$, household bleach (diluted 1:20 or 1:4), Menno-Florades (3\%), antibacterial dishwashing concentrate with tinosan HP100 $(0.4 \%)$, household disinfectant, Virkon $(0.5$ or $1 \%)$, Farmcleanse (1:10 dilution), hand sanitizer (62\% ethanol, undiluted), denatured ethanol (70\%), Cerama Klen $(2.5 \%)$, Sanibac (hydrogen peroxide at $595 \mathrm{~g} /$ liter and silver at $0.55 \mathrm{~g} /$ liter, dilution $2 \%$ ), inoculation buffer, and distilled water. All disinfectants were used at the manufacturer's recommended rate, diluted in distilled water, and used immediately. The mixture of infective sap and disinfectant was left for 1 min prior to being used to rub onto leaves of zucchini plants without buffer or abrasive. For controls, plants were rubbed with sap from healthy or ZYMV-infected plants without buffer or abrasive, and other plants were left uninoculated. In all, 5 or 10 zucchini plants (two leaves per plant) were used for each experimental treatment (disinfectants). Five plants were used for controls. A single newly emerged leaf was sampled from each plant up to 32 days after inoculation and tested individually by ELISA.

A follow-up experiment was done (similar to the one described above) that simulated virus transmission by trampling caused by movement of humans through a cucurbit crop, except that each experimental treatment consisted of six plants (one plant per pot). Treatments were applied 67 days after sowing and were (i) pumpkin leaves infected with ZYMV isolate Knx-1 trampled on 10 times with rubber-soled shoes, then healthy plants trampled; (ii) as for (i) but healthy leaves initially trampled; (iii) infected leaves trampled 10 times with rubber-soled shoes, then shoes soaked for
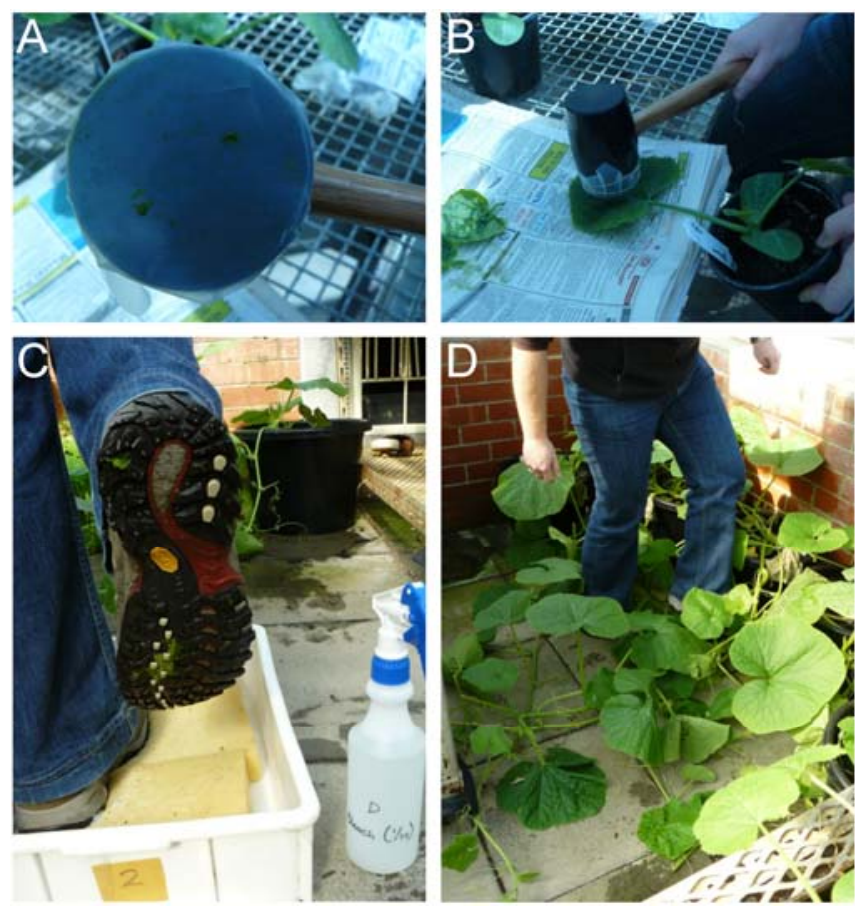

Fig. 1. A, Sap and crushed leaf material adhering to Parafilm covering a rubber mallet after tapping Zucchini yellow mosaic virus (ZYMV)-infected zucchini leaves; B, contaminated rubber mallet used to tap healthy zucchini plant; C, sap and crushed leaf material adhering to rubber shoe sole following trampling of ZYMVinfected zucchini leaves before dipping in footbath containing bleach (1:20 dilution); and $\mathbf{D}$, trampling healthy pumpkin plants with footwear contaminated with ZYMV. 
$30 \mathrm{~s}$ in a foot bath containing household bleach (diluted 1:20), then healthy plants trampled; and (iv) plants not trampled (Fig. 1C and D). A newly emerged leaf was sampled from each plant 49 days after trampling and tested individually by ELISA.

To establish whether disinfectants caused damage to metal cutting tools, carbon-steel surgical scalpel blades were dipped into each of the following: bleach (1:4 dilution), Farmcleanse, nonfat dried milk, household disinfectant, inoculation buffer, undiluted fresh sap, and distilled water for $30 \mathrm{~s}$ and then left to air dry. In addition, blades were dipped into bleach (1:4 dilution) for $30 \mathrm{~s}$ followed by distilled water for $30 \mathrm{~s}$. For each dipping solution, three blades were used. The blades were assessed visually to estimate the area corroded after 1 and $24 \mathrm{~h}$.

\section{Results}

Contact transmission. The number of plants that became infected by rubbing with leaves infected with isolates Knx-1, Cvn-1, Vic-1, and Nt-1 were 16/16, 15/16, 15/16, and 8/10, respectively (Table 1). Symptoms on infected plants were leaf mottle and distortion. Following cutting one, three, or five leaf petioles/plant with a scalpel blade contaminated with infective sap, $2 / 15,3 / 15$, and 10/15 plants, respectively, became infected. When fruit were cut, $0 / 5,2 / 5$, and $2 / 5$ plants became infected following cutting one, three, or five times, respectively. Infected plants developed mild mottle. None of the control plants ever became infected in these experiments.

In leaf crushing experiments, heavily crushed leaves (five taps) had extensive damage, often dying and falling off, whereas lightly (one tap) or moderately (three taps) crushed leaves had mild damage and often recovered. When healthy leaves were crushed with a rubber mallet contaminated with isolate Knx-1, 1/10, 6/10, and 9/10 plants became infected when lightly (one tap), moderately (three taps), and heavily (five taps) crushed, respectively (Table 1). When healthy leaves were crushed with a mallet contaminated with isolate Cvn-1, the corresponding figures were 4/10,3/10, and 6/10 plants. Infected plants developed leaf mottle and distortion. All plants became infected when infected leaves were rubbed onto healthy plants, and none of the healthy control plants ever became infected.

When a wheelbarrow was used to crush isolate Knx-1-infected leaves and then healthy pumpkin leaves, leaf damage was extensive, and many growing tips and leaves died, yet only 1/18 plants became infected. When plants were trampled with footwear, 9/18 plants became infected, despite leaf damage consisting of bruising and tearing. Leaf mottle, leaf distortion, and plant stunting developed in infected plants. None of the healthy control plants became infected.

Stability. Sap from leaves infected with isolates Knx-1 (two experiments) and Cvn-1 (one experiment) remained infective for up to $6 \mathrm{~h}$ after extraction, with 3 to $5 / 5$ plants becoming infected on each occasion, but none became infected after 24 or $48 \mathrm{~h}$ incubation periods (Table 2). With sap from plants infected with isolate $\mathrm{Nt}-1$ (one experiment), $1 / 5$ plants became infected $5 \mathrm{~min}$ after extraction but $0 / 5$ plants became infected after $30 \mathrm{~min}$ to $24 \mathrm{~h}$ time periods. With isolate Vic-1 (one experiment), sap remained infective up to $3 \mathrm{~h}$, with 1 to $4 / 5$ plants becoming infected after each time period, but none became infected after 6 or $24 \mathrm{~h}$. None of the control plants became infected.

In the two experiments on stability of ZYMV on different surfaces, ZYMV remained infective up to $6 \mathrm{~h}$ after extraction on all surfaces except human skin, with 1 to $5 / 5$ plants becoming infected (Table 3). After $24 \mathrm{~h}$, sap remained infective on plastic and leather but not on cotton, shoe sole, or metal. After 48 h, sap remained infective on tire only. With human skin, for each experiment, only $1 / 5$ plants became infected after $5 \mathrm{~min}$ but none after $30 \mathrm{~min}, 60$ min, or $6 \mathrm{~h}$. For the controls, all plants became infected when freshly extracted infected sap was used but none became infected when healthy plants were left uninoculated.

Disinfectants. In the two preliminary experiments, when plants were crushed (five taps per leaf) with a mallet contaminated with ZYMV-infected leaf sap and no disinfectant was applied, 3/5 and $5 / 5$ plants became infected (Table 4$)$. None became infected when

Table 1. Contact transmission of Zucchini yellow mosaic virus (ZYMV) to zucchini plants by leaf rubbing, cutting, and crushing

\begin{tabular}{|c|c|c|c|c|c|c|c|c|c|c|}
\hline \multirow[b]{2}{*}{ Treatment } & \multirow[b]{2}{*}{ ZYMV isolate } & \multicolumn{9}{|c|}{ Number of plants ZYMV-infected/total number of plants ${ }^{a, b}$} \\
\hline & & 1 & 2 & 3 & 4 & 5 & 6 & 7 & 8 & 9 \\
\hline \multirow[t]{4}{*}{ Rub } & Knx-1 & $6 / 6$ & $10 / 10$ & $5 / 5$ & $10 / 10$ & $5 / 5$ & $5 / 5$ & $5 / 5$ & - & - \\
\hline & Cvn-1 & $5 / 6$ & $10 / 10$ & - & - & - & - & - & $5 / 5$ & $5 / 5$ \\
\hline & Vic-1 & $5 / 6$ & $10 / 10$ & - & - & - & - & - & - & - \\
\hline & $\mathrm{Nt}-1$ & nt & $8 / 10$ & - & - & - & - & - & - & - \\
\hline Cut $\times 1$ & Knx-1 & - & - & $0 / 5$ & $2 / 10$ & $0 / 5$ & - & - & - & - \\
\hline$\times 3$ & Knx-1 & - & - & $1 / 5$ & $2 / 10$ & $2 / 5$ & - & - & - & - \\
\hline$\times 5$ & Knx-1 & - & - & $3 / 5$ & $7 / 10$ & $2 / 5$ & - & - & - & - \\
\hline Crush $\times 1$ & Knx-1 & - & - & - & - & - & $1 / 5$ & $0 / 5$ & - & - \\
\hline$\times 3$ & Knx-1 & - & - & - & - & - & $3 / 5$ & $3 / 5$ & - & - \\
\hline$\times 5$ & Knx-1 & - & - & - & - & - & $4 / 5$ & $5 / 5$ & - & - \\
\hline Crush $\times 1$ & Cvn-1 & - & - & - & - & - & - & - & $1 / 5$ & $3 / 5$ \\
\hline$\times 3$ & Cvn-1 & - & - & - & - & - & - & - & $1 / 5$ & $2 / 5$ \\
\hline$\times 5$ & Cvn-1 & - & - & - & - & - & - & - & $1 / 5$ & $5 / 5$ \\
\hline Control & $\ldots$ & $0 / 6$ & $0 / 10$ & $0 / 15$ & $0 / 10$ & $0 / 15$ & $0 / 15$ & $0 / 15$ & $0 / 15$ & $0 / 15$ \\
\hline
\end{tabular}

a A newly emerged leaf from each plant was tested individually up to 39 days after inoculation by enzyme-linked immunosorbent assay. nt $=$ not tested. $-=$ not part of experiment.

${ }^{\mathrm{b}}$ Numbers refer to individual experiments. 1 and 2, rub experiments where infected leaf gently rubbed onto healthy plant leaf. 3, 4, and 5, cut experiments where scalpel blade used to cut infected leaf petiole ( 3 and 4) or small fruit (5) before cutting healthy petioles. 6 to 9 , crush experiments where rubber mallet covered with Parafilm used to crush infected leaf then crush healthy plant leaf.

Table 2. Infectivity of Zucchini yellow mosaic virus (ZYMV) infective sap incubated for different time periods before inoculation to zucchini plants

\begin{tabular}{|c|c|c|c|c|c|c|c|c|}
\hline \multirow[b]{2}{*}{ ZYMV isolate } & \multicolumn{8}{|c|}{ Number of ZYMV-infected plants per incubation time periods prior to inoculation ${ }^{\mathrm{a}}$} \\
\hline & $5 \mathrm{~min}$ & $30 \mathrm{~min}$ & $60 \mathrm{~min}$ & $2 \mathbf{h}$ & $3 \mathbf{h}$ & $6 \mathrm{~h}$ & $24 \mathrm{~h}$ & $48 \mathrm{~h}$ \\
\hline Knx-1 & 4 & 4 & 4 & $\mathrm{nt}$ & 3 & 3 & 0 & 0 \\
\hline Knx-1 & 5 & 5 & 4 & 5 & 5 & 5 & $\mathrm{nt}$ & $\mathrm{nt}$ \\
\hline Cvn-1 & 5 & 3 & 4 & 3 & 3 & 5 & nt & nt \\
\hline Nt-1 & 1 & 0 & 0 & 0 & 0 & 0 & 0 & $\mathrm{nt}$ \\
\hline Vic-1 & 2 & 3 & 4 & 1 & 1 & 0 & 0 & $\mathrm{nt}$ \\
\hline
\end{tabular}

${ }^{a}$ Each treatment consisted of five plants of 'Blackjack' zucchini; nt = not tested. Newly emerged leaves from all plants tested individually up to 27 days after inoculation by enzyme-linked immunosorbent assay. Sap extracted from ZYMV-infected leaves was left at room temperature in porcelain bowls or metal trays for the incubation period, then resuspended in distilled water (1:1). 
the contaminated mallet was treated with Farmcleanse, Virkon, household bleach (two dilutions), household disinfectant, or Menno. Some plants became infected when Cerama Klen, dishwashing concentrate, ethanol, Isowipes, or distilled water were used. Crushed leaves had visible bruising and lacerations but remained attached. Infected plants developed mottle symptoms. None of the control plants became infected. No phytotoxic reactions were caused by any of the disinfectants because no additional damage was observed when compared with the control plants.

In the three main experiments, where disinfectant was added to sap from ZYMV-infected leaves prior to inoculation, no plants became infected with nonfat dried milk or bleach (1:4) (Table 4). When nonfat dried milk with Tween 20 was used, no plants became infected in two experiments but $2 / 5$ plants became infected in one experiment. With each Virkon dilution used (1 and $0.5 \%$ ), no plants became infected in one experiment but 1 to $2 / 5$ plants became infected in each of two experiments. With all other disinfectant treatments (denatured ethanol, household disinfectant, Farmcleanse, bleach [1:20], hand sanitizer, dishwashing liquid, Menno, Tween 20, Cerama Klen, and Sanibac), in at least one experiment more than half of plants tested became infected. Also, 4 to $5 / 5$ plants became infected in each experiment when inoculation buffer or distilled water were added. When infective sap was used without any disinfectant, all plants became infected. Infected plants developed mottle symptoms. None of the healthy control plants became infected. No phytotoxic damage to zucchini plants was caused by any of the disinfectants when plants were visually compared with control plants.

In the experiment in which ZYMV-infected leaves were trampled prior to trampling on healthy plants, $5 / 6$ plants became infected but none became infected when a footbath containing bleach (1:20) was used to wash footwear before trampling healthy leaves. Infected pumpkin plants developed mild mottle, distortion, and stunting. None of the control plants became infected.

Blades dipped in bleach developed surface corrosion within 5 min and 25 to $50 \%$ of their surface area was corroded after $1 \mathrm{~h}$. No corrosion developed on blades dipped in bleach followed by a distilled water rinse, Farmcleanse, inoculation buffer, or water. Fresh sap, nonfat dried milk, and household disinfectant caused corrosion to $<25 \%$ of the blade surface after $1 \mathrm{~h}$.

\section{Discussion}

This study shows that ZYMV can spread from infected to healthy cucurbit plants by leaf contact (rubbing and crushing) and

Table 3. Infectivity of Zucchini yellow mosaic virus (ZYMV) infective sap after incubation on seven surfaces for different time periods

\begin{tabular}{|c|c|c|c|c|c|c|}
\hline \multirow[b]{2}{*}{ Surface } & \multicolumn{6}{|c|}{ Number of plants ZYMV infected in two experiments per incubation time periods prior to inoculation ${ }^{\mathrm{a}}$} \\
\hline & 5 min & $30 \mathrm{~min}$ & $60 \mathrm{~min}$ & $6 \mathrm{~h}$ & $24 \mathrm{~h}$ & $48 \mathrm{~h}$ \\
\hline Cotton & 5,3 & $4, \mathrm{nt}$ & 5,5 & 3,1 & $\mathrm{nt}, 0$ & $\mathrm{nt}, 0$ \\
\hline Rubber shoe sole & 3,5 & $3, \mathrm{nt}$ & 4,4 & 3,0 & nt, 0 & nt, 0 \\
\hline Tire, inner tube & 5,5 & $3, \mathrm{nt}$ & 3,4 & 4,2 & $\mathrm{nt}, 0$ & nt, 1 \\
\hline Leather & 5,5 & $5, \mathrm{nt}$ & 5,4 & 1,0 & 0,1 & $\mathrm{nt}, 0$ \\
\hline Metal & 5,5 & $5, \mathrm{nt}$ & 5,5 & 3,1 & 0,0 & $\mathrm{nt}, 0$ \\
\hline Plastic & 5,5 & $5, \mathrm{nt}$ & 4,5 & 5,2 & 2,1 & $\mathrm{nt}, 0$ \\
\hline Human skin & 1,1 & $0, \mathrm{nt}$ & 0,0 & $\mathrm{nt}, 0$ & nt,nt & nt,nt \\
\hline Fresh infective sap & 5,5 & $\mathrm{nt}$ & $\mathrm{nt}$ & $\mathrm{nt}$ & nt & $\mathrm{nt}$ \\
\hline Control & 0,0 & $\mathrm{nt}$ & $\mathrm{nt}, 0$ &,- 0 & $\mathrm{nt}, 0$ & $\mathrm{nt}, 0$ \\
\hline
\end{tabular}

${ }^{a}$ Each treatment consisted of five plants of 'Blackjack' zucchini; isolate Knx-1 was used. Newly emerged leaves from all plants tested individually up to 30 days after inoculation by enzyme-linked immunosorbent assay; $\mathrm{nt}=$ not tested. Sap extracted from ZYMV-infected leaves was applied to surface, left at room temperature for each incubation period, and then wiped onto upper leaf surface of healthy plants. Numbers of plants infected in first and second experiments are separated by a comma.

Table 4. Inactivation of Zucchini yellow mosaic virus (ZYMV) in infective sap with various disinfectants

\begin{tabular}{|c|c|c|c|c|c|}
\hline \multirow[b]{3}{*}{ Treatment } & \multicolumn{5}{|c|}{ Number of ZYMV-infected plants ${ }^{a}$} \\
\hline & \multicolumn{2}{|c|}{ Mallet experiments ${ }^{b}$} & \multicolumn{3}{|c|}{ Sap experiments ${ }^{\mathrm{c}}$} \\
\hline & 1 & 2 & 1 & 2 & 3 \\
\hline Nonfat dry milk (20\% [wt/vol]) & nt & nt & 0 & 0 & 0 \\
\hline Nonfat dry milk $(20 \%[\mathrm{wt} / \mathrm{vol}])+$ Tween $20(0.1 \%)$ & $\mathrm{nt}$ & nt & 0 & 2 & 0 \\
\hline Tween $20(0.1 \%)$ & $\mathrm{nt}$ & $\mathrm{nt}$ & 4 & 5 & nt \\
\hline Bleach (1:20) (sodium hypochlorite at $42 \mathrm{~g} /$ liter, $4 \%$ chlorine) & 0 & 0 & 1 & 5 & nt \\
\hline Bleach (1:4) (sodium hypochlorite at $42 \mathrm{~g} /$ liter, $4 \%$ chlorine) & 0 & 0 & 0 & 0 & 0 \\
\hline Menno (3\% [wt/vol]) & 0 & 0 & 3 & 5 & nt \\
\hline Dishwashing liquid (0.4\% [wt/vol]) & 1 & nt & 2 & 5 & nt \\
\hline Disinfectant $(1: 20)$ (benzalkonium chloride $1.5 \%[\mathrm{wt} / \mathrm{wt}])$ & 0 & nt & 0 & 5 & $\mathrm{nt}$ \\
\hline Virkon $(0.5 \%$ [wt/vol] $)$ & 0 & 0 & 1 & 2 & 0 \\
\hline Virkon $(1 \%[\mathrm{wt} / \mathrm{vol}])$ & nt & nt & 1 & 1 & 0 \\
\hline Farmcleanse $(1: 10)$ & 0 & 0 & 0 & 4 & 9 \\
\hline Hand sanitizer ( $62 \%$ ethanol) & $\mathrm{nt}$ & nt & 2 & 5 & $\mathrm{nt}$ \\
\hline Denatured ethanol $(70 \%)$ & 0 & 2 & nt & 2 & 3 \\
\hline Cerama Klen $(2.5 \%$ [wt/vol], chlorine at $34 \mathrm{~g} / \mathrm{kg})$ & 2 & 2 & nt & 5 & nt \\
\hline Sanibac (2\%) (hydrogen peroxide at $595 \mathrm{~g} /$ liter) & nt & nt & nt & 5 & 10 \\
\hline Isowipe (70\% isopropyl alcohol) & 0 & 2 & nt & nt & nt \\
\hline Undiluted infective sap & 3 & 5 & 5 & 5 & 5 \\
\hline Distilled water & 2 & nt & 4 & 5 & 5 \\
\hline $0.1 \mathrm{M}$ phosphate buffer (inoculation buffer) & $\mathrm{nt}$ & nt & 4 & 5 & 5 \\
\hline Healthy sap & 0 & 0 & 0 & 0 & 0 \\
\hline
\end{tabular}

${ }^{a}$ Each treatment consisted of five plants of 'Blackjack' zucchini and isolate Knx-1; tip leaves from all plants tested individually by enzyme-linked immunosorbent assay up to 37 days after inoculation; $\mathrm{nt}=$ not tested.

${ }^{\mathrm{b}}$ In the two mallet experiments, a ZYMV-infected leaf was tapped with a Parafilm covered mallet five times, disinfectant was then applied to the Parafilm as an aerosol spray (three sprays), and healthy leaves were then tapped five times per plant. There were five plants per treatment.

${ }^{\mathrm{c}}$ In three sap experiments, sap was extracted from ZYMV-infected leaves and diluted (1:1) with disinfectant, then used immediately to inoculate plants without buffer or abrasive. There were 5 (experiments 1 and 2) or 10 (experiment 3) plants per treatment. 
on blades contaminated with sap from ZYMV-infected leaves. This knowledge provides important new information on the epidemiology of ZYMV because previously the only known methods of natural plant-to-plant transmission were via aphid vectors (23) and, occasionally, cucurbit seed $(11,15,38,40,44)$. ZYMV epidemics often develop very rapidly and contact transmission between plants is likely to contribute to this. We also found that ZYMV remains infective in dried sap at room temperature for up to $6 \mathrm{~h}$ and for up to $24 \mathrm{~h}$ after drying on different types of surfaces. Fortunately, however, it was inactivated by several disinfectants. Unlike other studies $(6,49)$ on the stability of infectivity of contact transmitted viruses, we did not apply any abrasive (e.g., carborundum) during inoculation of plants or dilute the sap with phosphate inoculation buffer or water during extraction or swabbing. The infectivity of ZYMV would have persisted longer if such procedures had been followed but we were attempting to reproduce scenarios likely to occur in cucurbit production systems.

Cucurbit plants have leaf surfaces covered with long, thick, sharp hairs (47) that easily cause fine scratches and wounds when leaves rub together; therefore, contact transmission can occur when healthy and infected plants intertwine (e.g., in pumpkin and melon crops) or leaves rub together through wind movement. The leaves of cucurbit plants also have large surface areas and are often soft. Therefore, although ZYMV concentration in leaves is lower than that of most other contact-transmissible viruses $(24,27)$, the large surface area and soft growth would provide increased opportunity for contact transmission by rubbing. ZYMV was also transmitted by crushing healthy leaves in the presence of sap from ZYMVinfected leaves. Our crushing and trampling experiments showed that ZYMV transmission readily occurred regardless of whether leaves had mild or extensive damage (lacerated and bruised). Such transmission can happen when plants are damaged by machinery or when humans or other large mammals move through a crop. Studies on whether ZYMV could be spread in nature by leaf rubbing caused by air movement (e.g., wind) alone should be done in an aphid-proof environment so that infected and healthy pumpkin or melon plants intertwine and move by wind only.

As mentioned earlier, a number of viruses, including PVS (16), HLFPV (22), CyMV, ORSV (19), TMV (25), and PVY (48), can be spread via contaminated cutting tools. ZYMV-contaminated cutting blades also transmitted ZYMV but three cuts of an infected leaf petiole or small fruit were needed before healthy plants became infected. Little sap was expressed following each cut because zucchini leaf petioles are hollow and their fruit dense. This may explain why several cuts of an infected petiole or fruit were needed with the same blade, such that sufficient sap coated it prior to cutting the healthy plant.

ZYMV remained infective for up to $6 \mathrm{~h}$ in sap contaminating six different types of surfaces. With human skin, however, little infectivity survived. Possibly, the virus was inactivated by previous use of skin care products or by rapid drying of sap within $5 \mathrm{~min}$ of application. With cotton and leather, absorption of sap started within $30 \mathrm{~min}$ and, by $6 \mathrm{~h}$, it was completely absorbed and dried. With shoe sole, tire, metal, and plastic surfaces, sap started to dry out within $60 \mathrm{~min}$ and was completely dried by $6 \mathrm{~h}$. Our findings indicate that ZYMV could be spread on clothing, footwear, and machinery for up to $6 \mathrm{~h}$ after contamination with sap from infected plants and up to $24 \mathrm{~h}$ on plastic and $48 \mathrm{~h}$ on tire. When such surfaces were tested under similar conditions, infectivity of PVX was retained for $10 \mathrm{~s}$ on leather, $3 \mathrm{~h}$ on rubber and human skin, and $6 \mathrm{~h}$ on cotton (49); and infectivity of PVS for $7 \mathrm{~h}$ on metal and $25 \mathrm{~h}$ on rubber (16). In contrast, TMV remained infective for several weeks on different surfaces (6).

We used two procedures to evaluate the effectiveness of disinfectants. In two preliminary experiments, a mallet was used to tap infected leaves then the disinfectant applied as an aerosol but, in the main experiments, disinfectant was added directly to sap extracted from infected leaves. The procedure was altered because of lack of uniformity in the amount of infective leaf material adhering to the mallet between successive plants and the likelihood that the amount of disinfectant applied as three sprays per plant would also have varied. The altered procedure ensured that the same volume of disinfectant and infected zucchini leaf sap was used in each of the experiments. When household bleach (1:4) was used, no plants became infected regardless of the method used. However, with bleach (1:20), Farmcleanse, and Virkon, no plants became infected using the mallet method but some did become infected when disinfectant was added to infective sap. Therefore, the latter procedure was a more reliable way to evaluate the effectiveness of disinfectants.

Considerations in determining the appropriate disinfectant to use need to include virus inactivation, ease of use (time of incubation), safety to personnel, availability, cost, and corrosiveness on equipment. For these reasons, we mostly included household and commercially available products in our studies. Both $20 \%$ nonfat dry milk and a 1:4 dilution of household bleach (sodium hypochlorite) prevented ZYMV infection. Similarly, Lewandowski et al. (25) found that treating TMV-contaminated cutting tools with a solution of nonfat dry milk plus Tween 20 or household bleach completely eliminated TMV transmission to petunia plants. Likewise, Kamenova and Adkins (22) found that $20 \%$ nonfat dry milk or $10 \%$ sodium hypochlorite completely prevented HLFPV infection from contaminated tools to hibiscus. When we tested nonfat dry milk with and without Tween 20 and Tween 20 alone, only nonfat milk alone consistently prevented ZYMV infection. Nonfat dry milk is a low-cost, low-toxicity, easily-disposed-of treatment that can be used in organic farming practices; therefore, it would be an ideal disinfectant. Sodium hypochlorite is considered extremely effective against all types of microorganisms and, when diluted, has low toxicity, is easy to use, and is relatively low cost (20). It was also effective at inactivating PepMV from glasshouse surfaces (33) and PVY (48), HLFPV (22), and Tomato chlorotic dwarf viroid (29) from contaminated cutting blades. However, a drawback to sodium hypochlorite solutions is that efficacy is reduced by organic matter and they are corrosive. We found that surface corrosion on steel blades started within 5 min of dipping in bleach containing sodium hypochlorite; however, rinsing in water reduced this. Commercial products are often recommended for decontaminating tools and surfaces from plant viruses and viroids $(33,43)$. We found that Menno-Florandes, Virkon, CeramaKlen, Sanibac, and Farmcleanse did not inactivate ZYMV completely. Moreover, alcohols such as denatured ethanol (70\%), hand sanitizer (62\% ethanol), and Isowipes (70\% isopropyl alcohol) were only partially effective.

This work raises the question as to whether contact transmissibility occurs with other potyviruses. From our initial experiments with other potyviruses infecting cucurbits, Papaya ringspot virus and Watermelon mosaic virus could both be transmitted readily when infected leaves were lightly rubbed on healthy leaves of cucurbit plants (10/16 and 14/16 plants infected, respectively; unpublished data). Further research is underway on the contact transmissibility of these two viruses. Also, Pea seed-borne mosaic virus sometimes reaches $100 \%$ incidences within pea crops with little evidence of aphid vectors being present (12), so perhaps, leaf-toleaf contact may provide another avenue for spread when plants interwine and wind moves them.

Integrated disease management (IDM) strategies for control of ZYMV in Australian cucurbit crops were described previously $(9,10)$. Recommended measures include isolation of new cucurbit plantings from older ones, removing any potential alternate virus reservoirs (weeds, volunteer cucurbit plants, or old finished or abandoned crops) during and between growing seasons, rogueing of plants with virus symptoms, use of reflective mulch, planting upwind of potential virus sources, manipulation of sowing date, deployment of tall nonhost millet barriers, and use of pumpkin and zucchini cultivars with the Zym resistance gene and cucumber cultivars with the zym gene. However, infection with ZYMV continues to be widespread in cucurbit crops in tropical and subtropical Western Australia, with extensive crop losses reported (10). This study identifies a previously unknown method of ZYMV transmission that may contribute to within-crop epidemics and is not being addressed by current IDM approaches. Cucurbit growers 
may be spreading ZYMV from infected to healthy plants inadvertently during production activities, including moving machinery through crops (e.g., during spraying or fertilizing), on weeding implements (e.g., hoes), during harvesting (e.g., knives), and during crop monitoring (e.g., footwear or clothing). Thus, the ease with which ZYMV was transmitted by contact was unexpected and highlights the importance of sanitation and hygiene practices in cucurbit production. Measures that address contact transmission such as washing down machinery, disinfecting cutting tools and surfaces, and limiting handling and movement within crops have now been included within modified integrated management strategies for viruses of cucurbits.

\section{Acknowledgments}

This research was funded by Horticulture Australia Ltd. projects VG06022 and VG01728. We thank E. Gajda for assisting with ELISA.

\section{Literature Cited}

1. Bananej, K., Keshavarz, T., Vahdat, A., Salekdeh, G. H., and Glasa, M. 2008. Biological and molecular variability of Zucchini yellow mosaic virus in Iran. J. Phytopathol. 156:654-659.

2. Bawden, F. C. 1964. Plant Viruses and Virus Diseases. The Ronald Press Company, New York.

3. Blua, M. J., and Perring, T. M. 1989. Effect of Zucchini yellow mosaic virus on development and yield of cantaloupe (Cucumis melo). Plant Dis. 73:317-320.

4. Brey, C. W., Johnson, G. D., and Blodgett, S. L. 1988. Survey of Montana grasses for wheat curl mite (Acari: Eriophyidae), the vector of wheat streak mosaic virus. J. Agric. Entomol. 15:173-181.

5. Brierley, P. 1962. Transmission of some gladiolus viruses on tools in harvesting flowers and corms. Plant Dis. Rep. 46:505.

6. Broadbent, L., and Fletcher, J. T. 1963. The epidemiology of tomato mosaic IV. Persistence of virus on clothing and glasshouse structures. Ann. Appl. Biol. 52:233-241.

7. Brock, R. D. 1952. The use of trisodium phosphate as an inactivating agent for plant viruses. J. Aust. Inst. Agric. Sci. 18:41-43.

8. Clark, M. F., and Adams, A. N. 1977. Characteristics of the microplate method of enzyme-linked immunosorbent assay for the detection of plant viruses. J. Gen. Virol. 34:475-483.

9. Coutts, B. A., and Jones, R. A. C. 2005. Incidence and distribution of viruses infecting cucurbit crop in the Northern Territory and Western Australia. Aust. J. Agric. Res. 56:847-858.

10. Coutts, B. A., Kehoe, M. A., and Jones, R. A. C. 2011. Minimising losses caused by Zucchini yellow mosaic virus in vegetable cucurbit crops in tropical, sub-tropical and Mediterranean environments through cultural methods and host resistance. Virus Res. 159:141-160.

11. Coutts, B. A., Kehoe, M. A., Webster, C. G., Wylie, S. J., and Jones, R. A. C. 2011. Zucchini yellow mosaic virus: biological properties, detection procedures and comparison of coat protein gene sequences. Arch. Virol. 156:2119-2131.

12. Coutts, B. A., Prince, R. T., and Jones, R. A. C. 2009. Quantifying effects of seedborne inoculum on virus spread, yield losses and seed infection in the Pea seed-borne mosaic virus-field pea pathosystem. Phytopathology 99:1156-1167.

13. Desbiez, C., and Lecoq, H. 1997. Zucchini yellow mosaic virus. Plant Pathol. 46:809-829.

14. Desbiez, C., Wipf-Scheibel, C., and Lecoq, H. 2002. Biological and serological variability, evolution and molecular epidemiology of Zucchini yellow mosaic virus (ZYMV, Potyvirus) with special reference to Caribbean islands. Virus Res. 85:5-16.

15. Fletcher, J. D., Wallace, A. R., and Rogers, B. T. 2000. Potyviruses in New Zealand buttercup squash (Cucurbita maxima Duch.): yield and quality effects of ZYMV and WMV 2 virus infections. N. Z. J. Crop. Hortic. Sci. 28:17-26.

16. Franc, G. D., and Bantarri, E. E. 2001. Transmission of viruses. Pages 159175 in: Viruses and Virus-Like Diseases of Potatoes and Production of Seed-Potatoes. G. Loebenstein, P. H. Berger, A. A. Brunt, and R. H. Lawson, eds. Kluwer Academic Publishers, Dordrecht, The Netherlands.

17. Grafton-Cardwell, E. E., Perring, T. M., Smith, R. F., Valencia, J., and Farrar, C. A. 1996. Occurrence of mosaic viruses in melons in the Central Valley of California. Plant Dis. 80:1092-1097.

18. Gibbs, A. J. 1977. Tobamovirus group. CMI/AAB Descriptions of Plant Viruses No. 184

19. Hu, J. S., Ferreira, S., Xu, M. Q., Lu, M., Iha, M., Pflum, E., and Wang, M. 1994. Transmission, movement and inactivation of cymbidium mosaic and odontoglossum ringspot viruses. Plant Dis. 78:633-636.

20. Jeffrey, D. J. 1995. Chemicals used as disinfectants: active ingredients and enhancing additives. Rev. Sci. Tech. Off. Int. Epiz. 14:57-74.

21. Jensen, D. D., and Gold, A.H. 1955. Hosts, transmission and electron microscopy of cymbidium mosaic virus with special reference to cattleya leaf necrosis. Phytopathology 45:327-334.
22. Kamenova, I., and Adkins, S. 2004. Transmission, in planta distribution and management of Hibiscus latent Fort Pierce virus, a novel tobamovirus isolated from Florida hibiscus. Plant Dis. 88:674-679.

23. Katis, N. I., Tsitsipis, J. A., Lykouressis, D. P., Papapanayotou, A., Margaritopoulos, J. T., Kokinis, G. M., Perdikis, D. C., and Manoussopoulos, I. N. 2006. Transmission of Zucchini yellow mosaic virus by colonising and noncolonising aphids in Greece and new aphid species vectors of the virus. J. Phytopathol. 154:293-302.

24. Koenig, R. 1978. Potexvirus group. CMI/AAB Descriptions of Plant Viruses No. 200.

25. Lewandowski, D. J., Hayes, A. J., and Adkins, S. 2010. Surprising results from a search for effective disinfectants for Tobacco mosaic virus-contaminated tools. Plant Dis. 94:542-550.

26. Lisa, V., Boccardo, G., D'Agostino, G., Dellavalle, G., and d'Aquilio, M. 1981. Characterization of a potyvirus that causes zucchini yellow mosaic. Phytopathology 71:667-672.

27. Lisa, V., and Lecoq, H. 1984. Zucchini yellow mosaic virus. CMI/AAB Descriptions of Plant Viruses No. 282.

28. Luis-Arteaga, M., Alvarez, J. M., Alonso-Prados, J. L., Bernal, J. J., GarciaArenal, F., Lavina, A., Batlle, A., and Moriones, E. 1998. Occurrence, distribution and relative incidence of mosaic viruses infecting field-grown melon in Spain. Plant Dis. 82:979-982

29. Matsuura, S., Matsushita, Y., Usugi, T., and Tsuda, S. 2010. Disinfection of Tomato chlorotic dwarf viroid by chemical and biological agents. Crop Prot. 29:1157-1161.

30. Matthews, R. E. F. 1981. Plant Virology, 2nd ed. Academic Press, New York.

31. McKirdy, S. J., Jones, R. A. C., and Sivasithamparam, K. 1998. Determining the effectiveness of grazing and trampling by livestock in transmitting white clover mosaic and subterranean clover mottle viruses. Ann. Appl. Biol. 132:91-105.

32. McLean, G. D., Burt, J. R., Thomas, D. W., and Sproul, A. N. 1982. The use of reflective mulch to reduce the incidence of watermelon mosaic virus in Western Australia. Crop Prot. 1:491-496.

33. O'Neill, T., Spence, N., Mumford, R., and Skelton, A. 2003. Pepino mosaic virus of tomato-new results on virus persistence and disinfection. Factsheet 20/03. Horticultural Development Council. UK. http://www.hdc org.uk/publication/2003-pepino-mosaic-virus-tomato-\%E2\%80\%93-newresults-virus-persistence-and-disinfection

34. Perring, T. M., Farrar, C. A., Mayberry, K., and Blua, M. J. 1992. Research reveals pattern of cucurbit virus spread. Calif. Agric. 46:35-40.

35. Riedle-Bauer, M. 2000. Zucchini yellow mosaic virus in Cucurbita pepo var. styriaca: epidemiology, strategies of control. Cucurbit Genet. Coop. Rep. 23:114-116.

36. Sarra, S., Oevering, P., Guindo, S., and Peters, D. 2004. Wind-mediated spread of Rice yellow mottle virus (RYMV) in irrigated rice crops. Plant Pathol. 53:148-153.

37. Sarra, S., and Peters, D. 2003. Rice yellow mottle virus is transmitted by cows, donkeys and grass rats in irrigated rice crops. Plant Dis. 87:804-808.

38. Schrijnwerkers, C. C. F. M., Huijberts, N., and Bos, L. 1991 Zucchini yellow mosaic virus; two outbreaks in the Netherlands and seed transmissibility. Neth. J. Plant Pathol. 97:187-191.

39. Sill, W. H. 1953. Some characteristics of the wheat streak mosaic virus and disease. Trans. Kans. Acad. Sci. 56:418-424.

40. Simmons, H. E., Holmes, E. C., Gildow, F. E., Bothe-Goralczyk, M. A., and Stephenson, A. G. 2011. Experimental verification of seed transmission of Zucchini yellow mosaic virus. Plant Dis. 95:751-754.

41. Spence, N. J., Basham, J., Mumford, R. A., Hayman, G., Edmondson, R., and Jones, D. R. 2006. Effect of Pepino mosaic virus on the yield and quality of glasshouse-grown tomatoes in the UK. Plant Pathol. 55:595-606.

42. Svoboda, J., and Polak, J. 2002. Distribution, variability and overwintering of Zucchini yellow mosaic virus in the Czech Republic. Plant Prot. Sci. 38:125-130.

43. Timmermann, C., Muhlbach, H. P., Bandte, M., and Buttner, C. 2001. Control of mechanical viroid transmission by the disinfection of tables and tools. Pages 151-156 in: Proc. 53rd Int. Symp. Crop Prot. Gent, Belgium.

44. Tobias, I., Szabo, B., Salanki, K., Kuhlmann, H., and Palkovics, L., 2008 Seedborne transmission of Zucchini yellow mosaic virus and Cucumber mosaic virus in Styrian Hulless group of Cucurbita pepo. Page 189 in: $\mathrm{Cu}-$ curbtiaceae 2008, Proc. IXth EUCARPIA Meet. Genet. Breed. Cucurbitaceae. M. Pitrat, ed. Avingnon, France.

45. Todd, J. M. 1958. Spread of potato virus X over a distance. Pages 132-143 in: Proc. 3rd Conf. Potato Virus Diseases. Lisse, Wageningen, The Netherlands.

46. Ullman, D. E., Cho, J. J., and German, T. L. 1991. Occurrence and distribution of cucurbit viruses in the Hawaiian Islands. Plant Dis. 75:367-370.

47. Whitaker, T. W., and Bohn, G. W. 1950. The taxonomy, genetics, production and uses of the cultivated species of Cucurbita. Econ. Bot. 4:52-81.

48. Wintermantel, W. M. 2011. A comparison of disinfectants to prevent spread of potyviruses in greenhouse tomato production. Plant Health Progress. Online publication. doi:10.1094/PHP-2011-0221-01-RS

49. Wright, N. S. 1974. Retention of infectious potato virus $X$ on common surfaces. Am. Potato J. 51:251-253.

50. Zhao, M. F., Chen, J., Zheng, H. Y., Adams, M. J., and Chen, J. P. 2003. Molecular analysis of Zucchini yellow mosaic virus isolates from Hangzhou, China. J. Phytopathol. 151:307-311. 